University of Nebraska - Lincoln

DigitalCommons@University of Nebraska - Lincoln

2012

\title{
Whither the new great game in Central Asia?
}

Stephen Blank

US Army War College, stephen.blank@conus.army.mil

Follow this and additional works at: https://digitalcommons.unl.edu/usarmyresearch

Blank, Stephen, "Whither the new great game in Central Asia?" (2012). US Army Research. 185.

https://digitalcommons.unl.edu/usarmyresearch/185

This Article is brought to you for free and open access by the U.S. Department of Defense at DigitalCommons@University of Nebraska - Lincoln. It has been accepted for inclusion in US Army Research by an authorized administrator of DigitalCommons@University of Nebraska - Lincoln. 


\title{
Whither the new great game in Central Asia?
}

\author{
Stephen Blank \\ Strategic Studies Institute, US Army War College, Carlisle Barracks, PA 17013, United States
}

\section{A R T I C L E I N F O}

\section{Article history:}

Received 12 October 2011

Accepted 27 January 2012

\begin{abstract}
A B S T R A C T
This paper represents an assessment of the present great game or new great game in Central Asia among the major external and internal political actors three. It finds that the game is probably intensifying and at the same time serves the purposes of Central Asian governments in helping them preserve domestic security. Thus the foreign rivalry serves multiple and paradoxical purposes. On the one hand states like Russia and China pursue great power aggrandizement and even neo-imperial policies there and on the other hand Central Asian states attach themselves to these countries in the hope of obtaining resources form them with which to augment their independence. At the same time as the United States announces its impending withdrawal from Afghanistan, it is already evident that the rivalry among the other major actors is heating up. Moscow is pursuing military bases the right to intervene in the domestic affairs of members of the CSTO and its customs union and China is strengthening its commercial primacy in the area. And while all this is occurring simultaneously we see concern over succession issues in several states, the possibility of something resembling the Arab spring occurring, an outcome that greatly alarms Russian, Chinese, and local leaders, and of course, the uncertain prognosis in Afghanistan. Thus the international competition within and around Central Asia is likely to intensify.
\end{abstract}

Copyright @ 2012, Asia-Pacific Research Center, Hanyang University. Production and hosting by Elsevier Ltd. All rights reserved.
Today Central Asia faces serious deeply rooted challenges from within and without that will likely only intensify in the future. Indeed, Central Asia arguably stands on the brink of profound strategic changes in the decade to come. Although nobody knows how these changes will affect the region, most observers of Central Asia generally

\footnotetext{
Th Paper presented to the OSW Conference on Central Asia, Warsaw, November 9, 2011.

E-mail address: stephen.blank@conus.army.mil.
}

Peer-review under responsibility of Asia-Pacific Research Center, Hanyang University.

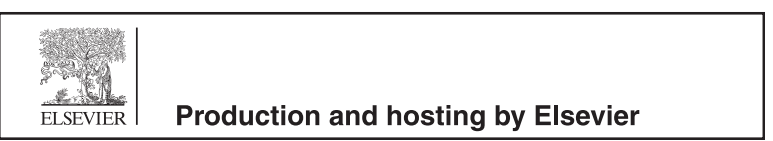

(though there are exceptions) argue that the region's stability is precarious at best. For example, one Indian account states that despite the relative and unexpected stability of the last twenty years, "the alleged stability of the region 'can vanish in no time' as it rests on a quicksand" (Kavalski, 2010, p. 93). Many of those changes pertain to the interaction of external actors in Central Asia what might be called "the new great game."

An accurate perception of the new great game would distinguish it from the old great game by virtue of the number of players, the depth and scope of their interactions, and the multi-dimensionality of their interactions (Blank, 2001, pp. 123-142). Both U.S. and foreign observers have captured this process. S. Enders Wimbush observes that,

The competitive context in Central Asia is formed primarily by two larger dynamics that sometimes 
overlap, intersect, converge, or collide. The first dynamic is created by outsiders. Central Asia is a caldron of large actors, including not only China and India but also the United States, the Gulf Arab states, Turkey, and to a lesser extent, Europe. Russia's strategic interests in the region continue; indeed they have intensified as the presence of other actors has become more pronounced. - The second dynamic is created by insiders. Central Asia today is a dynamic mix of local actors redefining themselves along both vertical and horizontal strategic axes. The state of post-Soviet Central Asia today adopt very different attitudes toward larger competitors, including India and China, to the extent that they adopt any attitude at all. Relations among these states are at best cautious at worst hostile; they affect and project different attitudes about their affinity for or antipathy to the East and West. While their strategic visions are often opaque or difficult to identify, little suggests that Central Asian states see themselves on a common pathway to the same future. (Wimbush, 2011, p. 260).

The Indian Kishan Rana similarly observes that to understand Central Asia, we should,

Visualize a three-dimensional, multiplayer chessboard, where a move by each protagonist produces eddies and backflows that affect all the others, and prompt counter-movements. Factor into this, the time as a fourth dimension, which takes this analogy beyond easy description. [Central Asia] resembles such a turbulent, volatile, and unpredictable scene owing to the mix of cooperation [and] contestation that marks virtually each bilateral relationship. The situation is all the more unpredictable because of the absence of fixed mooring points. [The region] thus offers a heady mix of bilateral, regional, and great power diplomacy in which the players weave bewildering nets of connections and counter arrangements. Some of the emerging developments appear contradictory, understandable only in a fluid context (Cited in Kavalski, 2010, p. 105).

When one takes account of the dynamics furnished by Kiril Nourzhanov it becomes clear just how complex this region truly is. Nourzhanov notedthe need to break away from a Western-derived threat paradigm that sees everything in terms of the great power rivalry commonly called the new great game and the main internal threat to regimes, namely insurgency (Nourzhanov, 2009, pp. 9495). While these threats surely exist, they hardly comprise the only challenges to Central Asian security. Thus he writes that,

Conventional security problems rooted in border disputes, competition over water and mineral resources, ubiquitous enclaves and ethinic minorities, generate conflict potential in the region and are perceived as existential threats by the majority of the local population. One of the very few comprehensive studies available on the subject arrived at the following conclusions. 1) relations among the countries of Central Asia are far from showing mutual understanding on the whole range of economic issues; 2) the most acute contradictions are linked to land and water use; and 3) these contradictions have historical roots and are objectively difficult to resolve, hence they are liable to be actualized in the near future in a violent form (Nourzhanov, 2009, pp. 94-95).

This is not just another academic analysis. In fact, border problems, mainly between Uzbekistan and all of its neighbors, have long impeded and today continue to retard the development of both regional security and prosperity (Umetov, 2009). Indeed, it is not too far to say that given the antagonism between Uzbekistan and its neighbors, especially Kyrgyzstan and Tajikistan, hostile relations and even the use of force is never far from a possibility. As a result of these trends a regional arms race has taken root in Central Asia. In 2007 alone military spending in Kazakhstan, Uzbekistan, and Turkmenistan rose by $48 \%$ (Nourzhanov, 2009, p. 95). As Nourzhanov further notes,

The bulk of the money would be spent on heavy weapons, fixed-wing planes, and navy vessels which is hard to explain by the demands of a fight against terrorism alone. Remarkably the danger of intraregional armed conflict is not seriously analyzed in any official document. The current Military Doctrine of Kazakhstan (2000) which talks about the tantalizingly abstract 'probability of diminished regional security as a result of excessive increase in qualitative and quantitative military might by certain states', may be regarded as a very partial exception that proves the rule (Nourzhanov, 2009, p. 95).

Much evidence corroborates this last point. For example Kazakhstan has increased defense spending by $800 \%$ in 2000-07 (Interfax-Kazakhstan Online, January 23, 2009a; Open Source Center, 2009a). And the state defense order is expected to double in 2009 (Kazakhstan Today Online, 2009b). Indeed, the trend toward militarization was already evident by 2003 (Blank, 2003, pp. 51-76).

Nourzhanov also notes that Central Asian leaders have put themselves or been put in an impossible position by having to recite public paeans to regional cooperation when they are contradicting it in their actions. Likewise, their invocations of Western threat scenarios that prioritize terrorism and insurgency are belied by events since only in Kyrgyzstan has there been an insurgency (Nourzhanov, 2009, pp. 94-95). Consequently the absence of regional cooperation is not a surprise, if anything it is overdetermined, but it also facilitates the coinciding great power rivalry (Allison, 2008, pp. 125-142). Organizations like the Shanghai Cooperation Organization (SCO) serve mainly to regulate Sino-Russian competition while allowing the Central Asian states to prevent either Russia or China from unilaterally "playing games" against them while enabling them to secure much needed resources from those two states. But it is hardly an effective security provider (Trenin, 2011, p. 252, Weitz, 2008a, p. 31).

Yet at the same time this already intense great power rivalry that is likely to intensify still further also represents a factor of stability in Central Asia. Paradoxically the geopolitical rivalry contributes to these regimes' stability even as it enmeshes them in a vortex of dynamic 
relationships that nobody can control. These countries simultaneously face the exigencies of both state-building i.e. assuring internal security and defense against external threats without sufficient means or time or resources to compete successfully with other more established states. Not surprisingly their primary concern becomes internal security and their continuation in power, hence the proliferation of multiple military forces, intelligence, and police forces in these countries, often enjoying more resources than do their regular armies, and their governments' recourse to rent-seeking, authoritarian, and clientilistic policies (Ayoob, 1999, pp. 247-260, Ayoob, 2002, pp. 127-148).

These facts possess significant relevance for any discussion of security, particularly in the Third World, including Central Asia, where the security environment is one of 'reversed anarchy' as described by Mikhail Alexiev and Bjorn Moeller. Alexiev, quoting Moeller, observes that,

While in modernity the inside of a state was supposed to be orderly, thanks to the workings of the state as a Hobbesian 'Leviathan,' the outside remained anarchic. For many states in the third World, the opposite seems closer to reality - with fairly orderly relations to the outside in the form of diplomatic representations, but total anarchy within (Alekseev, 2003, p. 12).

Similarly, Amitav Acharya observes that,

Unlike in the West, national security concepts in Asia are strongly influenced by concerns for regime survival. Hence, security policies in Asia are not so much about protection against external military threats, but against internal challenges. Moreover, the overwhelming proportion of conflicts in Asia fall into the intra-state category, meaning they reflect the structural weaknesses of the state, including a fundamental disjunction between its territorial and ethnic boundaries. Many of these conflicts have been shown to have a spillover potential; hence the question of outside interference is an ever-present factor behind their escalation and containment. Against this backdrop, the principle of non-interference becomes vital to the security predicament of states. And a concept of security that challenges the unquestioned primacy of the state and its right to remain free from any form of external interference arouses suspicion and controversy (Acharya, 2007, p. 41).

Indeed, for these states, and arguably even for transitional states like Russia, internal police forces enjoy greater state resources than do the regular armies, this being a key indicator of the primacy of internal security as a factor in defining the term national security (Cooper, 2007). Nevertheless, at the end of the day, it also still remains true that if they cannot defend themselves militarily against these threats, which have arisen due to a previous failure to provide security, they go under as classical thinking about hard security would predict.

Even though these states acknowledge themselves to face external threats of terrorism and narcotics trafficking from Afghanistan that then corrupts and corrodes the socio-political fabric in their countries, those threats are second to the preservation of the status quo as we have seen above. For example, after protracted bargaining in 2006 Uzbekistan granted Russia the right to use its airfield at Navoi as a base, but only under special conditions. Russia will only be able to gain access to Navoi in case of emergencies or what some reports called "force majeure" contingencies. In return Russia will provide Uzbekistan with modern navigation systems and air defense weapons. In other words Uzbekistan wanted a guarantee of its regime's security and Russian support in case of a crisis. But it would not allow peacetime Russian military presence there (Ferghana.ru Information Agency, December 22, 2006).

Indeed, to a certain extent, as Anna Matveeva has noted for Tajikistan, governments outsource part or most of the responsibility for dealing with those issues to other states and major power (Matveeva, 2005, pp. 133-153, 2006, pp. 7-33). Similarly in 2007 Kyrgyzstan invited Russia to bring its border guards back to Kyrgyzstan and to expand the size of its Kant Air Base because Bishkek could not afford to raise such troops on its own (RIA Novosti, 2007). More recently some Kyrgyz leaders urged, ultimately successfully that Kyrgyzstan, which is admittedly experiencing desperate economic conditions, join the Russian-sponsored Customs Union and thus sacrifice its economy to Moscow in an equally desperate effort to keep the state together (Eurasia Insight, 2011c). Even though Kyrgyzstan has been a member of the World Trade Organization for years and it has much lower import and export tariff rates than does the new Customs Union, it decided to assume the burden of heavier import tariffs. Consequently it will pay higher prices for goods imported from Russia, Kazakhstan, and the Middle East. Thus on top of everything else, it is forced to subsidize noncompetitive Russian goods to stay alive (Eurasia Daily Monitor, 2011).

This represents the ultimately destructive logic of outsourcing security to stay in power. But as a short-term expedient it has clearly proven its utility. Central Asian governments have also shown considerable willingness to associate themselves with Russia and China in regard to issues like external calls for liberalization and democracy because they regard democracy promotion from Washington as an outright threat to the status quo which, they maintain, boils down to a choice between them and Islamic fundamentalism. For that reason Central Asian think tanks and analysts have urged that Washington pursue a different strategy, one that emphasizes not democracy promotion but regional economic integration among Central Asian states and with neighbors like Afghanistan, India, and Pakistan (McDermott, 2006). However, on the basis of recent history there is little reason to believe that Washington can succeed in promoting genuine regional cooperation where the subjects of that cooperation are themselves unwilling to act.

Indeed, President Nursultan Nazarbayev of Kazakhstan expressly linked the US failure to win success for its crusade for democracy to the problems in Afghanistan. In November 2006 he publicly connected his and presumably his colleagues' frustration with Washington's democracy promotion campaign in a country and region with no democratic traditions to NATO's problems in stabilizing Afghanistan. Obviously the new Northern Distribution 
Network (NDN) road through Central Asia to Tajikistan exemplifies a strategy that could give a greater impetus to a focus on economic development and regional cooperation, i.e. external provision of goods that Kazakhstan and its neighbors could not provide for themselves (McDermott, 2006). But for it to succeed a long-term US presence, which is not in the cards, is essential.

As these examples show, states "outsource" aspects of their security to stronger neighbors to acquire resources or rents from the great powers which are then used to pay off clients, grant them the rents they seek, provide for domestic economic development, and stabilize both elite relationships and the overall state. For if they do not acquire these rents they have no choice but to turn quickly to external patrons, undermining the domestic situation and introducing political rivalries among the governing elite with dangerous crisis potentials for those elites. The Kyrgyz negotiations for the US to stay at Manas in 2009 openly illustrate this process, as does the aforementioned gambit to join the Customs Union. These great powers also include organizations within Central Asia: NATO's forces in Afghanistan and the US forces in Central Asia, NATO assistance in developing local militaries like that of Kazakhstan, Russian forces in the Tajik-Afghan border, and the SCO as a political security organization or Russia's military alliance, the Collective Security Treaty Organization (CSTO) which allegedly is developing an ever greater capability for bringing about security or using force against terrorist offensives.

Through such "multivector" diplomacy to gain security resources and assistance form the major external actors local governments can mitigate their potential external security dilemmas by exploiting great and major power rivalries to secure tangible security assistance that they could not otherwise produce on their own. Nazarbayev's protest above against US policies illustrates just how he but also his colleagues seek to sidestep the issue of democracy at home, employing constant balancing policies to obtain these goods from abroad like defense equipment, training, investors, etc. while avoiding contentious issues. Thus by securing China's commitment to build pipelines and buy gas, Central Asian states were then able to force Russia to pay higher prices for their gas and use the resources to strengthen their domestic and international positions. Through such diplomatic maneuvers they prevent or seek to prevent any of those external powers from dominating the regional security agenda if not the region. This external assistance is becoming ever more costly as the cost of energy and Central Asia's ability to export it to diverse markets rises and as the region's strategic importance grows. Those factors make investment in Central Asia ever more necessary for those powers who have interests or wish to see themselves as great international actors even as the costs go up. The security and material assistance they provide allows Central Asian regimes to worry less about external threats, and even to forego genuine regional integration while they can concentrate on exploiting those great power rivalries and the circumstances that grow out of them like energy rivalry to increase their domestic security, and leverage enough resources like energy rents with which to keep domestic challenges at bay.
Similarly these governments can use their appeals to major external actors to enlist their support for the local regimes' individual projects. The controversies among Kyrgyzstan, Tajikistan, and Uzbekistan over water use and the way that Russia has gotten involved in them exemplifies this process by which local governments solicit external support against their neighbors and draw Russia, who has ambitions to be the regional security manager into a morass from which there is no escape. This also illustrates how impossible it already is for Russia to realize these ambitions and maintain the loyalty of all of these states (Blank, 2010a, pp. 65-107). The same thing has happened recently to China who obviously does not relish being caught between Tajikistan and Uzbekistan (China Reform Monitor, 2011).

Thus the new great game materially assists domestic security in Central Asia and not only by reducing possibilities for any one power to dominate it. One way it contributes to regional security is through direct material assistance, e.g. China's $\$ 900$ Million loan to local governments after the SCO summit in 2005 and more recent investments, NATO's help through the Partnership for Peace, in building up Kazakhstan's armed forces, U.S. presence in Afghanistan and Kyrgyzstan, Russia's military presence in Tajikistan, Kyrgyzstan, and more recently Uzbekistan, and the growing scope of the exercises of SCO member forces against terrorism, separatism, and extremism, as displayed at the 2007 exercises. The SCO also functions in this way on behalf of regional governments.

Such assistance not only brings rewards in itself it also in turn stimulates anxieties about one or another power winning forcing the other state to make greater regional investments in Central Asia in order to retrieve their influence. Thus Chinese investments in pipelines from Kazakhstan and Turkmenistan have not only led Russia to invest in building their own new ones from these countries to Russia, it has also agreed to pay higher prices to gas producing states, Turkmenistan, Uzbekistan, and Kazakhstan to ensure that their gas goes through Russia to Europe not Asia (Graham-Harrison, 2008; InterfaxKazakhstan, 2008). Similarly the rivalry with the EU and America for influence over the direction of gas pipelines has also led Russia to discuss new energy deals with Kyrgyzstan and Tajikistan which both those states eagerly want and which gives them more resources to meet pressing internal challenges even if Russia raises its profile in their countries (McDermott, 2008; Marat, 2008). Indeed Moscow's elite appears to view any gain by China or America in Central Asia with unceasing paranoia. Thus its media repeatedly speculates about China's economic "conquest" of Central Asia and regards the handover of two obsolete Huey helicopters by Washington to Astana as the beginning of the end of Russian influence there (Abdullin, 2008; Panfilova, 2007).

Alternatively the benefits they gain from such multivector diplomacy where other actors are allowed in to provide security against domestic threats may be purely political as in the case of the SCO's political dimension. For Moscow and Beijing a key purpose of the SCO is to organize and articulate regional support for the ouster of American bases from Central Asia and to prevent the formation of any 
kind of American-led security organization there. At the same time, a second clear purpose of the SCO is to provide a forum for its members' virtually unanimous opinion that Washington should not interfere in their domestic arrangements. In other words, it functions, inter alia, as an organization of mutual protection and for the granting of the international legitimacy its members so desperately lack and crave. All the members support the continuation of the status quo and have united to reject calls for externally interested parties like Washington on behalf of democratic norms. Thus Russia and China provide both security and ideological cover for local regimes, allowing them to continue on their preset course with some sense that key players will back them up (Bailes, Dunay, Guang, \& Troitskiy, 2007). Uzbekistan in particular has been a master of such oscillation between east and west. Indeed, President Karimov said as much in December 2007, i.e.

There are still those who claim that there are disagreements between Uzbekistan on the one hand and the United States and European states on the other. It is not hard to see that they would like those disagreements to exist in order to benefit from them Uzbekistan, in its foreign policy, has adhered to mutually beneficial cooperation with and mutual respect for its close and far neighbors, including the United States and Europe. We will never change this policy. Moreover, we can say with certainty that the foundation for equal and mutually beneficial relations that suit our national interests is growing even stronger (Lillis, 2008).

In this fashion the SCO too acts to stabilize the domestic situation by allowing Central Asian states to institutionalize a forum where great power rivalries are visible but moderated, they have a real voice in its decisions and can talk on a collective basis to those great powers in order to get from them the resources that they believe they need and which the great powers feel they must contribute to their security. In this fashion the SCO allows the smaller members to exploit it for their own purposes in overcoming both the specter of "reversed anarchy"and great power domination.

Another likely manifestation of this process can already be seen in these new CSTO developments. We are likely to see increasing efforts by great powers to form partnerships with one or more Central Asian state to advance their own interests, or concurrently to block other powers' interests. China worked with other members of the SCO in 2008 to frustrate support for the independence of Abkhazia and South Ossetia in 2008. More recently it collaborated with Uzbekistan to frustrate Russian efforts to intervene in Kyrgyzstan's domestic crises in 2010 (Blank \& Kim, in press).

\section{Impending strategic transformations}

Nevertheless Central Asia stands on the brink of major and profound strategic changes many of which stem from the dynamics of this new great game. These impending changes derive from the following external factors: the US withdrawal from Afghanistan by 2014, well known overlapping and concurrent regional and global transformative processes like the rise of China and of India, decline of Europe, the centrality of energy and of the rivalries for access to it, Islamic self-assertion that takes multiple national or religious and often violent forms most notably in Afghanistan, Indo-Pakistani rivalry, Russia's unending quest for a neo-colonial hegemony in Central Asia, most recently expressed in Vladimir Putin's call for a Eurasian union, and the absence of any regional harmony among Central Asian states themselves (Eurasia Insight, 2011b). Second, and at the same time, every Central Asian state's domestic governance has become a matter of international concern because of the pervasive corruption, degradation of social infrastructures and environment, misrule, authoritarianism, repression, and the widespread fear of a potential Islamic insurgency. These widespread pathologies - not too strong a word - lie at the root of these states' vulnerability to Islamic radicalism or to any of the forms that internal upheaval might assume due to that misrule and the ensuing degradation of social, economic, and environmental conditions (International Crisis Group, 2009).

Third, the Arab spring, even if it is not likely to spread anytime soon to Central Asia as most analysts seem to feel, has heightened both Central Asian and Russian rulers' concern about these regimes' stability. Thus on April 13, 2011 Russia's anxiety about the possibility of the Arab revolutions spreading to Central Asia was the topic of a public discussion in the Duma. Members of the Duma and Deputy Foreign Minister Grigory Karasin called on these states to make timely reforms from above lest they be swept away like North African governments. Since Russia's goals are stability, without which these states cannot draw closer to Russia he recommended the formation from above of a civil society, international and inter-religious peace, responsibility of leaders for the standard of living of the population, the development of education and work with youth (Duma.gov.ru, April 13, 2011). In other words, Karasin called on Central Asian leaders to emulate Moscow's own efforts to build a "Potemkin democracy." Clearly this is not enough and no mention is made of economic development or freedom or genuine political reform. Clearly Russia is only willing to tolerate cosmetic reforms and it is doubtful that Central Asian leaders will even approach those limits let alone go beyond them. Indeed, only Kazakhstan's President Nursultan Nazarbayev acted in this manner and typically he preempted Russia.

What is equally important here is that Central Asian leaders believe in this threat and act upon it. In particular Moscow and Tashkent are alert to this possibility happening in Uzbekistan. Thus on April 14, 2011 when President Medvedev came to Tashkent Karimov told him that,

Nevertheless, I am convinced that everything happening in Uzbekistan in terms of ensuring the region's security and stability, the current events in North Africa and the Middle East and the emerging situation in Afghanistan are all issues that Russia and Uzbekistan cannot disregard, primarily from the perspective of synchronizing our positions and conducting an open exchange of views on the situation and the issues to be addressed in the nearest future. (http:// eng.kremlin.ru/news/2380, June 14, 2011).

Medvedev tellingly replied that, 
With regard to current international issues, you are absolutely right: the world is facing very serious challenges. This year began with the so-called Arab Spring, which has created a completely new situation in the Middle East and North Africa. In all likelihood, the international consequences of what has happened there will persist over a considerable period of time. We are certainly interested in ensuring that these events follow a clear and predictable scenario, because we are bound by numerous invisible threads with these countries, not only economic relations and trade, but also extensive humanitarian and cultural ties. They can be very positive or they can become quite complicated, and sometimes even destructive. Therefore, it is essential for us to discuss everything that relates to our closest neighbors, to ensure that we protect the national interests of our states and our nations. Russia has always held an open position in this area, we have discussed in detail nearly all key issues over the telephone, decided on the steps we will take and coordinated our foreign policy in many respects. I think this is extremely valuable, and it is a reflection of trust we have developed between our states. We intend to continue in this vein in the future, and I am very pleased that we are going to hold such consultations once again now, although they will be brief in terms of time but comprehensive in their content, so I once again want to thank you for the invitation. I hope that during my current working visit to Uzbekistan we will cover a wide range of issues of Russian-Uzbekistani cooperation, both bilateral and multilateral. (http://eng.kremlin.ru/news/2380, June 14, 2011).

Medvedev further stated, "We are interested that (future) events develop scenarios that are understandable and predictable for us." (Chaihana, Radio Free Europe Radio Liberty, 2011).

Both Moscow and Tashkent, to judge from their leaders' statements, charge that the Arab revolutions were instigated by outside by unnamed actors who sought access to Arab energy resources and sought to find ways to cooperate to forestall repeat performances in Central Asia (Orange, 2011). Thus Medvedev discussed plans to undermine Russia by fomenting revolutions. In March 2011 he stated that,

Look at the current situation in the Middle East and the Arab world. It is extremely difficult and great problems still lie ahead. In some cases it may even come to the disintegration of large, heavily populated states, their break-up into smaller fragments. The character of these states is far from straightforward. It may come to very complex events, including the arrival of fanatics into power. This will mean decades of fires and further spread of extremism. We must face the truth. In the past such a scenario was harbored for us, and now attempts to implement it are even more likely. In any case, this plot will not work. But everything that happens there will have a direct impact on our domestic situation in the long term, as long as decades (http://eng.kremlin.ru/ transcripts/1804, February 22, 2011).
These statements clearly apply to the US and Europe as Russian officials still publicly claim that the US had and still has a conscious plan that it has implemented to promote revolutions to democratize Central Asia (Nikolaev, 2011, pp. 57-62). But while this is certainly not nor has it ever been the case in Central Asia, it is Russia that instigated the Kyrgyz upheaval in 2010 (Blank, 2010b).

Therefore we should be alert to the possibility of state failure in one or more Central Asian states. Indeed, it could happen almost suddenly without warning. A recent analysis of North Korea reminds us that the more repressive and artificially maintained the regime is the more sudden and precipitous is its fall. Likewise, the worse the level of oppression, e.g. state violence as in Uzbekistan, is, the greater is the nightmare upon liberation (Kaplan and Denmark, 2011, pp. 12-13). Succession crises may be not only something Central Asian governments have in common given the nature of their governance, but also in each country such crises could become the major threat to the stability of the state, not just the particular or current regime there. In turn that succession crisis and ensuing crisis of the state could then possibly create an opening for a genuine Islamic movement to attempt to seize power. Likewise, although it does not seem likely right now, in the future one or more of these states could fall prey to a form of unrest analogous to what we now see in the Arab world (Clem, 2011, pp. 228-241). Certainly in the past Central Asian elites have viewed the prospect of civil strife in one country as a harbinger of the spread of that unrest across the region so this could actually come about in the future (Blank, 2007).

Nevertheless, nobody has taken advantage of this opportunity to institute reforms, quite the opposite. In Kazakhstan, President Nursultan Nazarbayev called for an instant election rather than a palpably stage-managed referendum to give him life tenure because that latter option was too egregious a move in the current climate. Meanwhile in Uzbekistan, an already draconian state in many ways, we see a further crackdown on mobile internet media along with denials by government agencies throughout the area that revolution is possible. Indeed, Uzbekistan has taken control over cellular companies there instructing companies to report on any suspicious actions by customers and on any massive distributions of text messages through their cellular lines (Lukyanov, 2011; Sadykov, 2011). Uzbekistan and Turkmenistan have also instituted news blackouts (Fitzpatrick, 2011; Shestakov, 2011; Voloshin, 2011). Azerbaijan too has attacked Facebook and Skype (Eurasia Insight, 2011a).

Such moves emulate the Draconian laws put in place by Russia and, Iran, and Kazakhstan as a result of the earlier color revolutions of 2003-05, the Iranian elections and Xinjiang uprisings of 2009, and China's move to intensify its already harsh controls on the Internet in 2011 (New York Times, 2011). These harsh moves against electronic media come on top of a situation demonstrating that press freedom in Eurasia is at its "lowest ebb" in over a decade (Maher, 2011). Meanwhile, in Azerbaijan, where unrest has been growing since late 2010 in response to the regime's moves to crackdown on dissent and Islamic agitation (not necessarily the same thing), large demonstrations are now 
occurring. Thus the Azeri government, seeing the failure of earlier tactics is now trying to work with influential Western media outlets to change public opinion so that it will believe no changes are expected even as mild criticism is tolerated. Similarly the government will organize tours from Western elites to persuade people that the West is cooperating with Baku, and it will raise pensions, salaries, and social services while either co-opting or suppressing the opposition (Baku, Azadilq, in Azeri, April 27, 2011, FBIS SOV, April 29, 2011).

Meanwhile Russia, joined by Central Asian states, seem intent on snuffing out reform and extending repression, not reform. Thus they have agreed, with the notable exception of Uzbekistan, to allow the CSTO, Moscow's military alliance with Central Asia, to perform the counterrevolutionary mission of suppression of internal upheavals within Central Asia, i.e. it is to be Russia's and to a much smaller degree, Central Asia's gendarmerie in the region (Blank, 2011). As a result of these factors the ongoing great power rivalry for influence in Central Asia, great and middle power rivalry has steadily intensified over the past few years, and is likely to do so for the following reasons which include the factors listed above.

Yet these are by no means the only sources of strategic transformation that are likely to affect Central Asia. Other factors making for transformation include:

- The likely intensification of great power, middle power, and Central Asian powers' engagement in Central Asia as the US withdraws and other actors strive to fill that vacuum. That intensification is a natural reaction to the downgrading of the US presence but it also reflects the following considerations.

- Because few leaders or governments believe that the Karzai government can survive a US withdrawal, the fear of a likely Taliban victory will galvanize local and nearby actors to compete to provide security as a much greater perception of threat from Islamic movements both from Afghanistan and Pakistan and from within Central Asian states, China, and Russia will arise often through deliberate government action. These factors are naturally closely tied to the perception of a vacuum in the event of a US withdrawal. Indeed analysts publicly worry about the fact that there is no backup strategy if the current ISAF/US strategy fails and in any cases allied governments are already looking for the exits. As US resources decline due to withdrawal and likely pressure on the budget, as is already occurring, regional anxiety will grow. Even if local governments do not comment much publicly about their fears, they are clearly hedging their bets and anticipating that they will have to assume at least some of the burden relinquished by Washington and NATO and that the burden will be in Central Asia not only Pakistan. Certainly Russian sources think this way and it is likely that the Uzbek government does too (Olsson, 2011, pp. 7-10; Jurgens 2011, pp. 4-12).

- The probable imminence of successions in Uzbekistan and Kazakhstan during this decade are also likely in the former case to lead to serious policy disruption if not worse. Indeed, we can already see the succession dilemma playing out in Kazakhstan. Turkmen President Sapirmurad Niyazov's sudden death in 2006 that led to what essentially was a struggle between heirs and a rapid coup d'etat by his successor Gurbanguly Berdymukhammedov, reportedly forced Nazarbayev to start thinking about succession in 2007 and it also alerted these clans who had hitherto not challenged him or the regime to follow suit. The result has been something of a series of continuing intrigues around this issue. According toStratfor.com,

Nazarbayev decided to step down in 2010 in order to be able to bolster whoever succeeded him and keep the peace. But the infighting proved too strong and risky, compelling Nazarbayev's supporters to name him“Leader of the Nation"-meaning he would always be in charge, not matter the position. The declaration was more a safety net than anything. The political theater surrounding rumors of succession decisions grew more dramatic over the past year, leading to the decision in January to call for a snap election for April. (www. stratfor.com, March 31, 2011).

At the same time he had originally planned to call for a referendum to certify his position and make it unassailable till 2020. Unfortunately Western governments communicated their unhappiness with this move and it certainly seemed impolitic as the Arab revolution gathered steam. So it was shelved and a snap presidential election called, thereby anticipating what Moscow would advocate in April 2011, namely the illusion of democratic choice (Makarin, 2011, www.stratfor.com, April 4, 2011a). Nevertheless the election was widely reported to have major shortcomings and Nazarbayev's political advisor Yermukhamet Yertsyayev told reporters that "I think the president is going to run the country for ten years more, and if someone in the West doesn't like it, they'll have to get used to it" (Lally, 2011).

However, in the meantime a game of balancing rival clans and factions continues while members of the inner circle, especially his daughter and son-in law, Timur Kulibayev, who are worth an estimated $\$ 2.5$ billion, become targets of corruption investigations abroad and bywords for corruption (Courtney, 2011). Under these circumstances it is not surprising that in the wake of his election Nazarbayev announced his intention to strengthen the Parliament and regional governments while deconcentrating central executive power (www. stratfor.com, April 8, 2011b). Whatever democratizing implications of his plan or ambitions for democracy Nazarbayev has, this move widens the circles of elites, dilutes the clans and factions close to him, and strengthens his hand to pick his successor while diffusing power so that nobody can amass too much power in the future. Nazarbayev's charge to his new government is to reduce corruption although that is hard to do given the corruption at the top. Second, Yertsybayev apparently envisages reforms from the top to create state-led parties of power and of opposition (Socor, 2011). This system would allegedly be a "Presidential-Parliamentary system" able to function in Nazarbayev's absence. And there are rumors that Kulibayev would duly lead the opposition party, thus 
confirming the continuation of a kind of Potemkin democracy (Najibullah, 2011).

This plan has apparently infuriated opponents of the regime but they are in no position to stop it. It would appear that Nazarbayev's concept of reform is to ensure a smooth transition to his successor whoever that may be, not to strengthen the overall system's responsiveness to society. Instead he apparently aims at building a relatively closed but seemingly self-sustaining system of Presidential-Parliamentary relationships. But this is likely to be a chimera in the absence of the rule of law, governmental accountability, and genuine reform. Indeed, it may lead to new authoritarianism or to sustained political strife after Nazarbayev leaves the scene (Kumkova, 2011a). Since the succession remains unresolved and nobody can stop the ruling family's corruption or machinations to revise the constitution whenever it likes, it is doubtful that genuine democracy can be initiated from the top or that the nature of the state will change substantially as long as Nazarbayev rules and possibly for some time after that. Whether it works or not, this and other trends in Kazakhstan highlight the unresolved nature of the succession and the fact that the astute economic policies followed until now depend too much on one man's wisdom. Despite his great achievements this is not the best augury for the future.

The situation in Uzbekistan looks much worse in the event of a contested succession that seems likely from this vantage point. A 2010 Norwegian analysis identified several flashpoints around Uzbekistan as we go into the future and a contested succession can only aggravate these challenges. This analysis found that,

Uzbekistan's economic and political setup are highly problematic and involve issues that will have to be resolved sooner or later, including widespread poverty, tensions between radical Islamists and secular elites, rapid population growth and environmental degradation. A combination of these problems may lead to an armed conflict with Uzbekistan, or to an Uzbekistani attack on a neighbor to gain more land and resources, or to rally the population around the regime and divert attention from domestic problems. Around the Ferghana Valley, in northeastern Turkmenistan and in southwestern Tajikistan there are significant groups with more or less Uzbek identities that could play a role in such a conflict. (Anker, Baev, Brunstad, Overland, \& Torjesen, 2010, p. 136).

Accordingly the authors concluded that,

The biggest country in the region in terms of population, Uzbekistan is at the same time the nation facing the greatest danger of violent escalation of overlapping social and political conflicts. There is also a very substantial risk of spillover of internal instability or 'horizontal' escalation of hostilities beyond Uzbekistan's borders. In all three of our scenarios, Uzbekistan is a regional source of instability of some kind - whether through implosion and protracted war of attrition between Islamic networks, political clans, and security forces; or through aggressive actions toward its neighbors or due to increasingly brutal authoritarian rule. The proposition that Uzbekistan could reform and become a positive force in the region has not been judged plausible. (Anker et al., 2010, p. 141).

Still worse, at least two of Central Asia's states may fairly be described as failing states, i.e. Kyrgyzstan and Tajikistan, while Paul Quinn-Judge of the International Crisis Group believes that Uzbekistan is not far behind (QuinnJudge, 2009). Tajikistan's pathologies are well known (International Crisis Group, 2009). And Kyrgyzstan, which is anything but an autocracy, is perched precariously on the brink of ungovernability and subject at any times to mass unrest, either ethnic or political, as its own officials admit. And while its leaders claim to be building democracy, this only applies to the ornamental or dignified parts of the state not its effective governing aspects. Indeed, in some of their public statements they openly worry about the country falling apart (Marat, 2011a). In Kyrgyzstan these effective aspects of governance are often carried out not just on the basis of regional, clan, tribal, or ethnic affiliation, or by the government, but also by thinly disguised criminal enterprises (Marat, 2006). Therefore rhetoric aside, we cannot and should not term Kyrgyzstan a democracy or a state that is building one. Indeed, it is barely a consolidated state and it is a cautionary example to all of its neighbors who believe that it exemplifies all the dangers and none of the benefits of democracy.

- The possibility or even some would say likelihood of an Arab spring or color revolution type of upheaval in one or more country which could spread to neighbors and now draw in the CSTO acting as the gendarme of Central Asia. Also raises the specter of significant strategic transformation. Here it should be noted that the possibility of a "color revolution," Arab spring type upheaval, or some other form of revolutionary crisis links together related but ultimately different phenomena that are and will be based on the peculiar individual characteristics of each country. For instance, a succession crisis might trigger what in other countries has come about due to phony elections or in the Arab cases an expression of pent-up anger at years of misrule, corruption, and repression. The key point is that while there are similarities in all these cases, the individual dynamics of each country are likely to be the decisive factors behind any such upheaval should one occur.

Other continuing factors making for meaningful strategic change include:

- The intense rivalry among Russia, China, India, Pakistan, and the West for energy access and energy security that manifests itself in the rivalry for pipelines through Central Asian states

- The already visible commercial and strategic rivalry between Moscow and Beijing for hegemony here at the same time that they share a joint antipathy to the US position in Central Asia which combines efforts at enhancing the US' military and commercial presence in Central Asia, mainly through support for alternative pipelines to Russia's preferences. 
- Iran's demand "for a place in the sun" in its region which may include Central Asia and the Caucasus, including Afghanistan, and which accompanies its unrelenting efforts to gain a nuclear weapon.

- Indo-Pakistani rivalry over both Central Asia and Afghanistan as well as traditional areas like Kashmir

- Transformations in the nature of war ranging from cyber strikes in Central Asia, which have already occurred, to nuclear proliferation among Iran, India, and Pakistan (Kumkova, 2011b)

- The inability of these governments to deal concretely with pressing global economic and environmental issues at a time of persistent, long-lasting crisis

\section{The new great game}

Although many scholars dislike the term "great game" or "new great game" because to them these terms smack of echoes of the imperial rivalry of the nineteenth and twentieth centuries; the point of the term "new great game" is precisely that we have surmounted the era and what we see now is something entirely different. This difference does not, however, mean that we have seen the end of policies resembling those of the age of imperialism. First, there is an enormous competition among the US, Russia, India, and China for military bases in Central Asia. All of these states either have bases, have had bases, or have sought bases in Central Asia in the last decade and the growth of the CSTO eloquently testifies to the continuation of the military dimension in the great powers' search for security in Central Asia. The different factor today is that local governments of their own accord are actively soliciting US military involvement if not that of Russia and China for the reasons outlined above (Kucera, 2011a).

Similarly we see what amounts to naked land grabs by the great powers, albeit on a relatively small scale in Central Asia. For example, Tajikistan has been induced to surrender to China 1100 square miles (2000 ha of land) to Chinese farmers. Allegedly this "rectification" of the borders ensures Tajikistan's inviolability of its borders, definitively solves its border problems with China, and ensures its stability “for decades to come.” (Laruelle \& Peyrouse, 2011c) But that statement implies that without this agreement Tajikistan's security vis-à-vis China would have been questioned if not at risk. And the further details of this agreement indicate the visible presence of Chinese power in Dushanbe's decision-making.

This agreement, allegedly based on a prior accord between the two governments in 2002 that was ratified again in 2010 cedes about 1000 square $\mathrm{km}$ in the Pamir Mountains to China, about 1 percent of Tajikistan, albeit a sparsely settled area (Singh, 2011; Pannier, 2011a, 2011b). Tajikistan's government hailed this as a victory because China had actually claimed some $28,000 \mathrm{~km}$ and settled for only about 3.5 percent of its claims. Moreover, Shukhrob Sharipov, Director of the Presidential Center for Strategic Studies, argued that, "If we hadn't decided to transfer the land (at this time), we would not have been able to resist China's pressure" (Pannier, 2011a, 2011b). This remark basically sums up the nature of Central Asian states' relationship to China.
This agreement clearly also conformed to the pattern we have seen in China's earlier expansionist activities vis-à-vis Kazakhstan and Kyrgyzstan. Worse yet, the raw material resources in the land ceded by Tajikistan allegedly equals the entire Chinese investment in Tajikistan to date. Thus China has allegedly recouped its investment at no cost to itself and has both the land and its resources as well as maintaining its investments and penetration of Tajikistan (Singh, 2011). On the other hand, these deals triggered a strong political backlash in all three countries against China and its perceived intentions. Perhaps Tajikistan's backlash was triggered more by the fact that between 1500 and 2000 Chinese farmers will settle another 2000 ha of land beyond the border agreement (Pannier, 2011a, 2011b). According to the opposition Tajikistan is becoming increasingly economically dependent on China due to its large investment in the area and this causes great resentment. Attacks on Chinese workers in other countries also testifies to this backlash across Central Asia.

At the same time, we might also point to the following likely developments in what presently constitutes the great power rivalry for influence in Central Asia. In the current configuration it is not only the great powers: US, Russia, China, India, and the EU who are pursuing influence, access, and leverage in Central Asia, indeed, middle ranking powers: Pakistan and Iran are clearly enhancing their efforts to improve relations with all the actors in Central Asia as are South Korea and Japan in order to obtain economic-political and possibly even strategic benefits.

Third, beyond these aforementioned trends, regional actors like Kazakhstan and Uzbekistan have already begun to take actions to shape their security environment as their power and wealth grows and second, in the expectation of both the US withdrawal and concurrently intensified SinoRussian pressure upon them and rivalry with each other for precedence in Central Asia. Indeed, we even find Uzbekistan and Kazakhstan thinking of projecting their influence and power into neighboring Central Asian states like Kyrgyzstan either through investments as in Kazakhstan's case or in more direct military threats and interference in other states' economic activity as we often see with Uzbekistan (Weitz, 2008b). But we also find that on occasion, e.g. during the Kyrgyz revolution of 2010, these two governments engaged each other in substantive disussions about possible reactions and power projection into Kyrgyzstan.

Fourth, international financial institutions (IFI) like the Asian Development Bank, the World Bank, the UN and its agencies like the UN Development Program (UNDP), are also heavily involved in major projects and policies here. Finally, and perhaps most important, as a mark of distinction from the imperial past, each of the Central Asian states is now a fully empowered (at least formally) state and sovereign foreign policy actor. Consequently each one is conducting its own version, insofar as possible, of a multivector or more accurately balancing approach attempting to balance all the multiple external sources of benefits to them to enhance their domestic stability.

Therefore, based on the foregoing we can point to certain likely developments regarding interstate rivalry and especially great or major power rivalry and competition in Central Asia for the foreseeable future. First, because 
the effort to define and gain control over Central Asia or at least gain lasting influence over it coincides with the escalation of the war in Afghanistan since 2008 the stakes involved in the effort to direct the destiny of Central Asia Central Asia have grown. Though the following assertion by Ahmed Rashid may somewhat exaggerate the importance of these stakes, from the standpoint of regional governments this is actually an understatement because they believe their fate is linked with that of Afghanistan. Thus Rashid writes that,

The consequences of state failure in any single country are unimaginable. At stake in Afghanistan is not just the future of President Hamid Karzai and the Afghan people yearning for stability, development, and education but also the entire global alliance that is trying to keep Afghanistan together. At stake are the futures of the United Nations, the North Atlantic Treaty Organization (NATO), the European Union, and of course America's own power and prestige. It is difficult to imagine how NATO could survive as the West's leading alliance if the Taleban are not defeated in Afghanistan or if Bin Laden remains at large indefinitely.(Rashid, 2009, p. xxxix)

Those stakes also involve the other states of Central Asia as well since it is widely believed that a Taliban victory in Afghanistan makes them a prime target for insurgency in the future. Especially in the light of fears for the stability of the Karzai government and the overall region in the light of a US withdrawal, every state, large or small, is jockeying for greater capability and power in the region and some, like Uzbekistan, clearly expect both to have to project power and that they will be asked to project power to neighbors to preserve stability in the area after 2014. Second, as Emelian Kavalski has observed, the nature of what we call the "new great game," the proliferation of actors in a continuous multi-dimensional struggle for influence in Central Asia precludes any one actor obtaining previous levels of imperial or neo-imperial domination, though Russia still tries for it, and has led to a situation where, given the concurrent proliferation of actors and agents operating in Central Asia,

The simultaneity of these two dynamics reveals that the agency of external actors is distinguished not by an imperial desire for the control of territory, but by the establishment of 'niches of influence.' Consequently, the notion of the 'new great game' comes to characterize the dynamics of processing, selection and internalization of some externally promoted ideas and not others. (Rashid, 2009, p. xxxix).

Third, in view of the impending US military withdrawal it is not clear that Washington, confronted by wrenching fiscal stresses, either has the vision or the means to develop or implement a coherent post-Afghanistan Central Asian strategy, a vacuum could well develop there with regard to the US position that will inevitably be filled by other actors. Certainly there is no sign yet of what will replace the US military presence after 2014 and no sign of a formal document worked out with Afghanistan that delineates the extent to which a US presence in the region will look like. In the absence of such a policy statement every regional actor is hedging its bets and preparing for the worst in the future, a trend that most likely means intensified competition among the great, regional, and local powers for influence in Central Asia.

Indeed, arguably the US presence is the most important stabilizing factor in the region, not only against the threats posed by the Taliban, Al-Qaida, and other affiliated terrorist groups. Of its own accord the US presence balances Russia and China's efforts at either economic or military domination by virtue of the large infusion into the region of US logistic support through the Northern Distribution Network (NDN) that materially aids employment, investment, and infrastructural development, along with military training for local governments. Likewise the US and ISAF presence obviously protect the entire region against the incursion of the Taliban and affiliated criminal, drugrunning, and insurgent terrorist groups. Third, as external observes, e.g. China, understand, the US presence provides a huge enlargement of political and economic and military space for actors like India, which still lags behind in Central Asia as a competitor for influence, to aspire to a role equal to that of China or Russia in the future. Absent that US role it is likely that despite Russian support, China and Pakistan would succeed in checking any Indian ability to project meaningful economic or military power into the region or obtain genuine influence or contracts for energy supplies. Certainly China has far outpaced India to date throughout the region despite India's undeniable rising wealth and power (Laruelle \& Peyrouse, 2011b, Kavalski, 2010, Wimbush, 2011, pp. 259-282).

Only quite recently have US policymakers or former policymakers like Deputy Assistant Secretary of State Evan Feigenbaum been willing to concede that many US objectives have failed to materialize(Tynan, 2011). This realization also finds expression in high-level US think tank reports with which Feigenbaum was involved but that represented a consensus view among experts like the recent Project 2049 study that flatly said the US is failing to realize its regional objectives in Central Asia (Project 2049, 2011). Thus both policymakers and expert thinking about Central Asia has often become examples of dashed hopes and defective analysis.

Meanwhile, the chief spokesman for US Central Asian policy, Assistant Secretary of State for South and Central Asia, Robert Blake, testified before Congress that US policy in Central Asia is (in terms of programs and relationships) primarily bound up with the war in Afghanistan (Blake, Testimony, 2011). Yet since US troops are beginning to leave in 2011, and are supposed to be out of Afghanistan by 2014 except for a small training and advisory mission, and European governments have long been essentially looking for the exit, the question poses itself, can or will the United States and/or the West devise a coherent Central Asian strategy based on regional realities rather than external needs and perceptions? Previous evidence should incline us in all frankness to be very skeptical about this happening.

Those actors who could supplant the United States include not only the great powers but also middle powers. We can already see these other actors positioning themselves to act in lieu of the US to secure their aims. For 
example, it is already clear that Pakistan will sabotage any effort to obtain a negotiated peace by killing its partisans and encouraging the Taliban and other terrorist groups in their campaign, thereby poisoning relations further with Afghanistan and the US. Indeed, Pakistan, haunted by an obsession that any non-Taliban or Paksitani-influenced Afghanistan will be controlled in some way by India, has moved to improve relations with Central Asian states and especially with Moscow and Beijing as its relationship with Washington steadily deteriorates (Gilgit-Baltistan Times, 2011). But Pakistan is hardly alone in positioning itself for the new post-American Afghanistan and Central Asia. Russia has recently successfully forced Kyrgyzstan and Tajikistan to accept new Russian leases on bases or new bases that will last for years in those countries (Marat, 2011b; Kucera, 2011b). And China's burgeoning commercial presence has apparently already eclipsed that of Russia. And is likely to continue growing even if it is not supplanted by the overt deployment of military power in the region (Trenin, 2011, p. 234).

\section{Towards the future}

We have already highlighted the centrality of US strategy here and the fact that the absence of any clear statement about its future direction fosters increased rivalry and tension throughout Central Asia. Similarly the threat from a Taliban victory to the area is well known except for the fact that it is likely to intensify the already visible fissiparous tendencies threatening Pakistan. In that case both Central and South Asia could then be caught in a reciprocal whirlpool whereby instability in one area adds to instability in the second region and this process continues in a continuously vicious circle (Laruelle \& Peyrouse, 2011a, pp. 145-150).

Likewise we should be alert to the potential repercussions of a more overt Sino-Russian rivalry as China's superior power makes itself felt throughout Central Asia. Russia's example of coercive partnerships goes beyond its quest for bases to it new effort at a Eurasian customs union as part of its overall Eurasian Economic Union, EURASEC. One of the key motives is Russia's growing relative decline in commercial competitiveness vis-à-vis China in Central Asia, as this customs union clearly shows. Russian concern for its position is quite visible but it is unable to voice openly fears of rivalry with China due to reasons of its overall partnership with China against the United States. But what is happening in Central Asia is clear to observers. When the global economic crisis hit China invited Russia to join with it in contributing \$5 Billion each for an anti-crisis stabilization fund in the SCO to invest in Central Asian infrastructure. Moscow demurred and set about its own anti-crisis program for CIS members. China then went ahead on its own and created a $\$ 10$ Billion dollar stabilization fund for such investments in Central Asian members of the SCO in 2009.

Consequently Russian analysts already claim that "the interaction with China within SCO only weakens Russia's position in the long run" (Teploukhova, 2010, p. 93). Maria Teploukhova writes that,
Beijing is one of the major foreign policy partners of Moscow, bilateral dialog is well set, and the SCO cannot be regarded as a priority for further development or interaction. Even for military exercises both parties do not need the SCO - they can simply continue them in the bilateral format, as they do now. Meanwhile attempts to compete with China within the SCO are also doomed to failure, since for China the SCO is a matter of foreign strategy and for Russia it is a matter of prestige. Therefore, Moscow either has to agree to the position of second player (as it does now), or to spend much of its resources on real rivalry. Cooperation between the SCO and the Collective Security Treaty Organization helps to improve the position of Russia, but again the overall context implies that the structure is more oriented toward Central Asia than the Rusian Far East. (Teploukhova, 2010, p. 93).

Indeed, China's economic power grew so much in 2009 that Russia was forced to accept China's investments in Central Asia as a positive phenomena. Deputy Foreign Minister Sergei Ryabkov actually praised Chinese investment in Central Asia for its "transparency" (Open Source Center, 2009b)

Ryabkov further claimed that,

We believe that our friends and partners in Central Asia are appropriately meeting the situation and solving the task facing them in the sphere of economic and social development using the opportunities that present themselves as a result of cooperation with China. Hence this can only be welcomed (Open Source Center, 2009b).

Given the consistent paranoia with Moscow's elite has hitherto appeared to view any gain by China, or for that matter America, in Central Asia this is a profound change in rhetoric if not policy and a major concession to China. As a 2007 report of the Russian-Chinese Business Council observed,

Being a member of the SCO, China views other members of the organization as promising markets. It is China that wishes to be the engine behind the trade and economic cooperation within the framework of the SCO - China's intentions to form [a] so-called economic space within the SCO are well known. Owing to that fact, experts have been speaking about greater Chinese economic expansion in various parts of the world, including Central Asia. - Beijing has activated ties with all Central Asian countries and strives to comprehensively strengthen economic relations and the dependency of these countries on its market (Interfax, 2007).

\section{Consequently in Central Asia,}

China has steadily advanced, commercially speaking, into Central Asia. It is now second to Russia as a trading partner for Central Asia, and its volume of trade with the three Central Asian states it borders is already equal to that of Russia. China is also actively seeking to obtain oil and gas directly from the region, bypassing Russian territory and challenging one of Russia's core strategic 
goals, monopoly control of energy flows in Eurasia. China is already linked to oil fields in Kazakhstan's Caspian region and to gas fields in Turkmenistan by pipelines completed in 2009 (Graham, 2010, p. 65).

Clearly one of the impacts of this customs union, is therefore to divert Central Asian economies away from China by coercing them into a partnership with Moscow against Beijing's economic power. Moscow's quest for military bases in Central Asia is also not merely an antiAmerican maneuver, but also intended to keep China, who has previously expressed an interest in bases there, out (Mukhin, 2005). And this many-sided struggle among all the great powers for influence and access in Central Asia will undoubtedly continue if not grow in intensity as the US winds down its military presence in Afghanistan.

Indeed, Russia is falling ever more behind China in its ability to invest real resources and gain cooperation even though Central Asian govenrments universally fear China (Laruelle \& Peyrouse, 2009) If present trends continue into the long-term it is quite conceivable that the best Russia can hope for is to be the gendarme for Chinese investments in Central Asia and its "younger brother" there, a thoroughly unappetizing role for Russia. Unfortunately that is not the worst possible outcome. By continuing to pursue the will o' the wisp of empire Russia is systematically undermining the capacity of these states to meet their own contemporary economic and political challenges while essentially trying to keep them in a state of neo-colonial backwardness for its own benefit. This is, sad to say, an old script, and we know how it ends. If Russia is truly concerned about Central Asian security then time is running out for it to change its strategy and foster Central Asia's sovereign entry into the contemporary world. Otherwise Russia will either be China's gendarme or sitting atop a volcano or series of volcanoes that will inevitably explode because of the pressure imposed by Russian neo-imperialism and myopia. In Central Asia and elsewhere Moscow claims a great power status but it has neither the necessary vision nor capability to provide the responsible leadership the region might actually support. Here as elsewhere, to quote Robert Legvold, Russia seeks status not responsibility (Legvold, 1997, p. 67). Ultimately that quest, taken in the context of intensified geopolitical rivalry and threats to Central Asia and given Russia's capabilities and Central Asian realities, can only end in a violent confrontation from which nobody will benefit. Finally we must remember that whatever we say, Central Asians will have the last word and in that context regime change and even crisis may come unexpectedly, rapidly and with a surprise for all concerned parties. These possibilities duly heighten the need for the US to announce its future strategy and actually begin to implement it along with its European and other allies. According to the American expert on Central Asia, Daniel Burghart,

For too long, Central Asia has been defined in terms of what others sought to gain there, and to a certain degree that is still the case. What is different is that since 1991, the region has begun to define itself, both in terms of national identities that it never had before, and a regional identity that it is trying to create. (Burghart, 2009, p. 123).
But if Central Asia and the great powers with major interests there are to remain secure it is now time to see Central Asia not in those terms but in terms of what we need to invest in it to prevent the return or continuation of all the dysfunctional pathologies of the present "new great game."

\section{References}

Abdulin. (January 15, 2008). For Kazakhstan's army - a NATO heading. Marketing I Konsalting Internet Version, in Russian, January 9, 2008. FBIS SOV.

Acharya, A. (2007). Human security and Asian regionalism: a strategy of localization. In Amtiav Acharya, \& Evelyn Goh (Eds.), Reassessing security cooperation in the Asia-Pacific: Competition, congruence, and transformation (pp. 241). Cambridge, MA: MIT Press.

As quoted in Alekseev, M. (2003). Regionalism of Russia's foreign policy in the 1990s: A case of reversed anarchy. Donald W. Treadgold Papers. University of Washington, Henry M. Jackson School of International Studies. No. 37

Allison, R. (Summer, 2008). Virtual regionalism and regime security in Central Asia. Central Asian Survey, XXVII(2), 185-202.

Almaty. Interfax-Kazakhstan Online 2009, in Russian.

Almaty. Kazakhstan Today Online 2009. FBIS SOV, in Russian, February 24, 2009.

Almaty. Interfax-Kazakhstanjanuary 9, 2008. FBIS SOV, in Russian.

American Foreign Policy Council. (August 30, 2011). China Reform Monitor. NO. 916.

Anker, M., Baev, P. K., Brunstad, B., Overland, I., \& Torjesen, S. (2010). The Caspian Sea region towards 2025: Caspia Inc. national giants or trade and transit? Delft, Holland: Eburom.

Ayoob, M. (1999). From regional system to regional society: exploring key variables in the construction of regional order. Australian Journal of International Affairs, LIII(3), 247-260.

Ayoob. (2002). Inequality and theorizing in international relations: the case for subaltern realism. International Studies Review, IV(3), 127148 , and the works cited therein.

Bailes, A. J. K., Dunay, P., Guang, P., \& Troitskiy, M. (2007). The Shanghai cooperation organization. SIPRI Policy Paper No. 17. Stockholm: SIPRI. and the sources cited there.

Baku. (April 29, 2011). Azadilq. FBIS SOV. in Azeri, April 27, 2011.

The author attempted this kind of analysis in 2000 Blank, S. (2001). A Sacred place is never Empty: the external Geopolitics of the TransCaspian. In Jim Colbert (Ed.), Natural resources and national Security: Sources of conflict $\mathcal{E}$ the U.S. Interest (pp. 123-142). Washington, D.C Jewish Institute of National Security Affairs.

Blank, S. (2003). Central Asia's strategic revolution, regional power plays in the Caucasus and central Asia, NBR analysis. Seattle, Washington: National Bureau of Research, Asia.

Blank, S. (2007). Turkmenistan and central Asia after Niyazov. Carlisle Barracks, PA: Strategic Studies Institute, US Army War College.

Blank, S. (2010a). Energy and environmental issues in central Asia's security agenda. The China and Eurasia Forum Quarterly, VIII(2), 65-107.

Blank, S. (2010b). Moscow's fingerprints in Kyrgyzstan's storm. Central Asia Caucasus Analyst.

Blank, S. (September 26, 2011). The CSTO: Gendarme of Eurasia. Eurasia Daily Monitor.

Blank, S., \& Kim, Y. China's Hour in Central Asia? Recent Chinese policies in Central Asia, in press.

Burghart, D. (2009). Khans, Tsars, and Emperors: the changing nature of central Asia's security spectrum. In Bert Edstrom (Ed.), Security and development in Asia: New threats and challenges in the post-Soviet era (pp. 123). Stockholm: Institute for Development and Policy.

Medvedev to Karimov - Leave office voluntarilyJune 15, 2011. Chaihana: Radio Free Europe Radio Liberty.

Clem, R. S. (2011). From the Arab Street to the Silk road: implications of the unrest in North Africa for the central Asian States. Eurasian Geography and Economics, LII(2), 228-241.

Cooper, J. (2007). The funding of the power agencies of the Russian State. Power Institutions in Post-Soviet Societies, (6-7). www.pipss.org.

Kazakhstan's Succession Crisis: a Special Report Courtney, W. (April 5, 2011). The Father of Kazakhstan. International Herald Tribune.

Dmitry Medvedev held a meeting of the national anti-terrorism Committee in VladikavkazFebruary 22, 2011. http://eng.kremlin.ru/transcripts/1804.

Kyrgyzstan joins Russian-backed customs unionApril 14, 2011. Eurasia Daily Monitor.

Azerbaijan puts Skype in its sights2011. Eurasia Insight. www.euraisanet.org. 
Eurasian union proposal key aspect of Putin's expected Presidency2011. Eurasia Insight.

Kyrgyzstan: On the campaign trail in Moscow2011. Eurasia Insight.

Uzbek airfield is made available to Russia in emergenciesDecember 22, 2006 Ferghana.ru Information Agency.

Fitzpatrick, A. (February 4, 2011). Will the revolutions in the Middle East have an impact on Uzbekistan? Eurasia Insight, www.eurasianet.org.

Gilgit-Baltistan Times. (September 4, 2011). Russia-Pakistan renewed relationships. http://gbtimes.wordpress.com/2011/09/04/russiapakistan-renewed-relationships/.

Graham, T. (2010). The sources of Russia's insecurity. Survival, LII(1), 65.

Graham-Harrison, E. (January 22, 2008). China-Turkmen gas price seen setting new benchmark. Reuters.

Moscow. InterfaxNovember 15, 2007, in English, November 15, 2007, FBIS SOV.

International Crisis Group. (February 12, 2009). Tajikistan: On the road to failure. http://www.crisisgroup.org/library/documents/asia/central_ asia/162_tajikistan__on_the_road_to_failure.pdf.

Jurgens, Igor (Ed.). (2011). CSTO responsible security (pp. 4-12). Moscow: Institute of Contemporary Development.

Kaplan, R. D., \& Denmark, A. M. (May/June, 2011). The long goodbye: the future North Korea. World Affairs, CLXXIV(1), 12-13.

Emilian Kavalski quoting the Indian analyst R.R. Sharma in. India and central Asia: The mythmaking and international relations of a rising power 2010. London and New York: I.B. Tauris, Publishers.

Kazakhstan's leader pushes to empower the Parliament April 4, 2011. www. stratfor.com.

Kazakhstan's leader pushes to empower the Parliament April 8, 2011. www. stratfor.com.

Kazakhstan's succession crisis: A special report March 31, 2011. www. stratfor.com.

Kucera, J. (2011a). India's Tajikistan air base dreams die hard. Eurasia Insight, and the sources cited there. www.euraisanet.org.

Kucera, J. (2011b). Russia looking at military expansion in Tajikistan and Kyrgyzstan? Eurasia Insight, www.eurasianet.org.

Kumkova, K. (2011a). Kazakhstan: astana Powerbrokers Wrestling with the succession issue. Eurasia Insight.

Kumkova, K. (2011b). Central Asia: who's responsible for a malware blitz on government computers? Eurasia Insight, www.eurasianet.org.

Lally, K. (April 13, 2011). Kazakh President holds fast as Arab revolutions topple others. Washington Post, www.washingtonpost.com.

Laruelle, M., \& Peyrouse, S. (2009). China as a neighbor: Central Asian perspectives and strategies. Stockholm: Institute for Security, Development and Policy.

Laruelle, M., \& Peyrouse, S. (2011a). Mapping regional geopolitical understanding mapping central Asia. Indian Perceptions and Strategies, $145-150$.

Laruelle, M., \& Peyrouse, S. (Eds.). (2011b). Mapping central Asia: Indian perceptions and strategies, Farnham, Surrey, England.

Laruelle, M., \& Peyrouse, S. (2011c). China as a neighbor: Central Asian perspectives and strategies. Passim; Moscow, Interfax, in Russian, January 18, 2011, FBIS SOV, January 18, 2011; Dushanbe, Asia-Plus Online, in Russian, January 13, 2011, FBIS SOV, January 13, 2011; Moscow, Interfax, In English, April 28, 2010, FBIS SOV, April 28, 2010; Moscow, Interfax, in English, January 14, 2011, FBIS SOV, January 14, 2011

Legvold, R. (1997). The 'Russian question'. In Vladimir Baranovsky (Ed.), Russia and Europe: The emerging security agenda (pp. 67). Oxford: Oxford University Press for the Stockholm International Peace Research Institute (SIPRI).

Lillis, J. (January 23, 2008). US-Uzbekistan relations: Another step toward rapprochement? Eurasia Insight.

Lukyanov, F. (January 25, 2011). Learning from Libya and Singapore. Russia in Global Affairs, http://eng.globalaffairs.ru/redcol/Learning-from-Libyaand-Singapore-15124.

McDermott, R. N. (November 20, 2006). U.S. Foreign policy in central Asia: time for change? Eurasia Daily Monitor.

McDermott, R. (February 7, 2008). Rahmon effusive about: "Strategic partnership" with Russia. Eurasia Daily Monitor.

Maher, H. (May 5, 2011). Report: press freedom at lowest ebb' in more than a decade. Radio Free Europe Radio Liberty.

Makarin, A. (April 4, 2011). Kazakhstan: President Nursultan Nazarbayev will have to choose successor during the new term of office, Moscow, Kommersant. in Russian, April 4, 2011. FBIS SOV.

Marat, E. (October 2006). The state-crime Nexus in central Asia: State weakness, organized crime and corruption in Kyrgyzstan and Tajikistan. Washington and Uppsala: CACI\&SRSP Silk Road Paper.

Marat, E. (February 1, 2008). Gazprom might buy Kyrgyzgaz in coming months. Eurasia Daily Monitor.

Marat, E. (2011a). Who is instilling fear in Kyrgyzstan? Eurasia Daily Monitor.
Marat, E. (2011b). Russia seeks long-term military presence in Tajik, Kyrgyz bases. Tajikistan Newswire, http://www.universalnewswires. com/centralasia/tajikistan/viewstory.aspx?id=10247.

Matveeva, A. (2005). Tajikistan: evolution of the security sector and the war on terror. In Anna H. Ebnoether, Major Ernst. M. Felberhauer, \& Martin Malek (Eds.), Facing the terrorist challenge -Central Asia's role in international co-operation (pp. 133-153). Vienna and Geneva: Bureau for Security Policy of the Austrian Ministry of Defense, National Defense Academy, Vienna, Geneva Centre for the Democratic Control of Armed Forces in Cooperation with PIP-Consortium of Defence Academies and Security Studies Institutes.

Matveeva, A. (2006). EU stakes in central Asia. Chaillot Paper No. 91. Paris: Institute of Security Studies of the European Union.

Mukhin, V. (August 8, 2005). Poslednaya Nabrosok na Iuge. Nezavisimaya Gazeta.

Najibullah, F. (April 24, 2011). Who would succeed Kazakh President Nazarbayev? Eurasia Insight.

China creates agency to regulate cyberspace. (May 5, 2011). New York Times, www.nytimes.com.

Nikolaev, S. (2011). Central Asia in geopolitics: the American vector. International Affairs (Moscow), 2, 57-62.

Nourzhanov, K. (2009). Changing security threat perceptions in central Asia. Australian Journal of International Affairs, LXIII(1), 94.

Olsson, S. (2011). Afghanistan after 2014. In Jerker Hellstoem, Mikael Eriksson, \& Niklas Granholm (Eds.), Strategic outlook 2011 (pp. 7-10). Stockholm: FOI.

Open Source Center. (2009a). Foreign broadcast information service central Eurasia (Henceforth FBIS SOV).

Open Source Center. (2009b). OSC Feature, Russia, OSC analysis, "Russian officials Laud ties with China; observers express concerns. FBIS SOV.

Orange, R. (May 10, 2011). Uzbek President accuses the west of funding Arab revolts. The Telegraph, www.te.graph.co.news/worldnews/asia/ uzbekistan/8505104/Uzbek-president-accuses-

Panfilova, V. (November 28, 2007). China will dress Turkmenistani army: Pekin generously credits central Asian countries. in Russian. Moscow: Nezavisimaya Gazeta. FBIS SOV November 28, 2007.

Pannier, B. (2011a). Chinese move on to Tajik fields. Asia Times Online, www.atimes.com.

Pannier, B. (2011b). Tajikistan agrees to allow Chinese farmers to till land. Eurasia Insight, www.eurasianet.org.

Project 2049. (2011). Strengthening fragile partnerships: An agenda for the future of U.S.-Central Asia relations. Washington, D.C. http://www. project2049.net/documents/strengthening_fragile_relationships_ central_asia_feigenbaum.pdf.

Quinn-Judge, P. (October 15-16, 2009). Conventional security risks to central Asia: A summary overview. Paper Presented to the Conference, Energy, Environment, and the Future of Security in Central Asia, Understanding the Security Implications of Critical Energy and Environmental Issues, Rome.

Rashid, A. (2009). Descent into Chaos: The US and the Disaster in Pakistan, Afghanistan, and central Asia (2nd ed.). London: Viking Penguin Books.

Kyrgyzstan invites Russian border guards, offers to boost airbaseMay 21, 2007. RIA Novosti. http://en.rian.ru/world/20070521/65801511.html.

Sadykov, M. (March 15, 2011). Uzbekistan tightens control over mobile internet. Eurasia Insight, www.eurasianet.org.

Shestakov, Y. (April 1, 2011). Could the revolutionary fervor in North Africa reach the former Soviet central Asian states,? The Telegraph,

Singh, B. (January 28, 2011). Sino-Tajik border: Settlement or entrapment? New Delhi: Institute of Peace and Conflict Studies.

Socor, V. (April 15, 2011). Kazakhstan's Presidency initiates discussion on political reforms. Eurasia Daily Monitor

Sokhranit' Stabilnost' v Tsentral'noi Azii- Uchastniki Parlametnariskikh Situatsii v Gosdume, www.duma.gov.ru/news/273/71937/print=yes, April 13, 2011

Teploukhova, M. (2010). Russia and international organizations in the Asia-Pacific: agenda for the Russian far East. Security Index, XVI(2), 83.

Testimony before the house foreign affairs, committee, subcommittee on Europe and Eurasia, Robert O. Blake, Jr. Assistant secretary of State Bureau of South and Central Asian Affairs, March 10, 2011, http:// www.internationalrelations.house.gov/112/bla031011.pdf.

Trenin, D. (2011). Challenges and opportunities: Russia and the rise of China and India. In Ashley Tellis, Tavis Tanner, \& Jessica Keogh (Eds.), Strategic Asia 2011-12: Asia responds to its rising powers (pp. 252). Seattle and Washington, D.C: National Bureau of Asian Research.

Tynan, D. (February 24, 2011). Absent in Ashgabat: does the US need an Envoy in Turkmenistan? Eurasia Insight.

Umetov. (May 4, 2009). Uzbekistan-Kyrgyzstan: border Hassles abound. Transitions Online, www.tol.cz. 
Visit to Uzbekistan June 14, 2011. http://eng.kremlin.ru/news/2380.

Voloshin. (Spring, 2011). Don't expect Mideast-style revolution in central Asia. Global Asia, VI(1). http://globalasia.org/1.php?c=e379.

Weitz, R. (2008a). Kazakhstan and the new international politics of central Asia. Washington, D.C.: Central Asia Caucasus Institute, and the Institute for Security and Development Policy, Silk Road Paper.
Weitz. (2008b). Kazakhstan and the new international Politics of central Asia. No such study exists for Uzbekistan but there are abundant instances of its threats and forceful actions against its neighbors.

Wimbush, S. E. (2011). Great games in central Asia. In Ashley Tellis, Tavis Tanner, \& Jessica Keogh (Eds.), Strategic Asia 2011-12: Asia Responds to its rising powers (pp. 259-282). Seattle and Washington, D.C: National Bureau of Asian research. 